\title{
Evaluation of bacteriological quality of locally produced raw and pasteurised milk in Selangor, Malaysia
}

\author{
${ }^{1 *}$ Nordin, Y., ${ }^{1}$ Kwan, S.Y., ${ }^{1}$ Chang, W.S., ${ }^{1}$ Loo, Y.Y., ${ }^{1}$ Tan, C.W., ${ }^{1}$ Mohd Fadzil, S.N., \\ ${ }^{1}$ Ramzi, O.S.B., ${ }^{2}$ Kuan, C.H., ${ }^{3}$ Premarathne, J.M.K.J.K., ${ }^{1}$ Nor-Khaizura, M.A.R., \\ ${ }^{1}$ New, C.Y. and ${ }^{1,4}$ Son, R. \\ ${ }^{1}$ Department of Food Science, Faculty of Food Science and Technology, Universiti Putra Malaysia, 43400, \\ Serdang, Selangor, Malaysia \\ ${ }^{2}$ Department of Agricultural and Food Science, Faculty of Science, Universiti Tunku Abdul Rahman \\ (UTAR), Jalan Universiti, Bandar Barat, 31900 Kampar Perak, Malaysia. \\ ${ }^{3}$ Faculty of Livestock, Fisheries and Nutrition, Wayamba University of Sri Lanka, Makandura, Gonawila \\ 60170, Sri Lanka \\ ${ }^{4}$ Food Safety and Food Integrity, Institute of Tropical Agricultural and Food Security, Universiti Putra \\ Malaysia, 43400 UPM Serdang, Selangor, Malaysia
}

\begin{abstract}
Article history:
Received: 9 October 2018

Received in revised form: 10

November 2018

Accepted: 11 November 2018

Available Online: 12

November 2018
\end{abstract}

Keywords:

Bacteriological quality,

Raw milk,

Pasteurized milk,

Total plate count

DOI:

https://doi.org/10.26656/fr.2017.3(3).235

\begin{abstract}
High demand for milk has been observed amongst the Malaysian public. Hence, research in milk is essential to assure food safety in milk consumption. This study evaluated the quality of locally-produced milk and present of bacterial hazards in cow and goat milk. A total of 120 milk samples including thirty raw cow milk, thirty pasteurized cow milk, thirty raw goat milk and thirty pasteurised goat milk were collected from dairy farms, delivery milkman, marts and markets in Selangor, Malaysia. The bacteriological quality of milk was evaluated for the presence of Escherichia coli, mesophilic, and coliform bacteria. An acceptable standard limit of $<1 \times 10^{5} \mathrm{CFU} / \mathrm{mL}$ for the total bacterial count was used to indicate good quality of milk. Overall, all type of milk exceeded 100,000 CFU/mL. The pasteurized raw goat milk showed the highest $\left(7.16 \log _{10} \mathrm{CFU} / \mathrm{mL}\right)$ in total plate count while the pasteurized cow milk recorded as the lowest $\left(5.38 \log _{10} \mathrm{CFU} / \mathrm{mL}\right)$ in total plate count. Approximately half of the milk samples were contaminated with coliform bacteria and a proportion has exceeded the acceptable limit of $50 \mathrm{CFU} / \mathrm{mL}$. The presence of E. coli was detected in over $44 \%$ of the samples. Milk contaminated with the pathogenic $E$. coli can cause self-limited, watery to bloody diarrhea including severe diseases like haemolytic uremic syndrome (HUS). Hence, it is important to ensure the quality of milk for public health safety.
\end{abstract}

\section{Introduction}

In any dairy industries whether small, medium or large scale, milk quality control is essential. Milk consists of high nutritional components that allow rapid multiplication of bacteria especially under unsanitary production and mishandling of milk during storage. The bacteriological quality control is essential to identify the degree of contamination, enumeration of selected microorganisms and ensure that milk complies with the regulatory standards (Chatterjee et al., 2006; Muehlhoff et al., 2013). Principally, the scheduled bacteriological assessment of milk and milk products is important for public health protection.

In developing countries, the production of milk is said to be taken place below standard sanitary practices, ineffective farm management and hot tropic weather. All these conditions have contributed to spoilage and economic loss to the milk industry (Worku et al., 2012; Yuen et al., 2012). Importantly, the nature of milk enables it to be an excellent substrate for the growth of the microorganism. Hence, milk with high quality and safety is not easily accomplished (Worku et al., 2012).

While pasteurisation has improved the safety of milk, improper handling can lead to recontamination. The microbial spoilage in pasteurised milk mostly attributed by Gram-negative bacteria. This usually comes from inadequately cleaned and sanitized filling machines (Angelidis et al., 2016). Protection of milk after heating can be done through the application of standard hygiene 
in milk processing, right temperature and thermal conditions, and buying high quality of raw milk (Piotrowska et al., 2015).

The total plate count (TPC) at $10^{5} \mathrm{CFU} / \mathrm{mL}$ has been used as the standard by Malaysian regulatory. In addition, coliform and $E$. coli count was also included by Malaysian regulatory for evaluation of microbiological safety in milk. For farmers, high microbial load in milk resulted in higher milk selling price and hence pose economic loss to the local farmers.

The quality of pasteurised milk highly depends on the quality of the raw milk which acts as the starting materials (Angelidis et al., 2016). In Malaysia, pasteurised milk has not received sufficient attention and there is no reported data on the bacteriological quality of locally produced pasteurised milk.

Temperature is an important factor for the prevalence and proliferation of microorganism in milk (Reta and Addis, 2015). When milk is subjected to temperature abuse, the microorganisms can multiply to a higher level and may produce toxins. More so, a study from Brazil showed that deficient cold storage chain has contributed to the reduced quality of milk (Petrus et al., 2010). Therefore, it is interesting to evaluate the bacteriological quality of milk based on storage temperature at different collection points.

Hence, the aim of this study is to determine the bacteriological quality of cow and goat milk collected in Selangor, Malaysia. The total plate count, coliform count and $E$. coli count of milk samples were evaluated. Both raw and pasteurised milk of the dairy animals was assessed in this study. This study also evaluated the bacteriological quality of milk based on collection points, from farms to marketplaces. The milk samples from marketplaces including milk from mart and market (night market, agro fair and Ramadhan bazaar).

\section{Materials and methods}

\subsection{Sample collection}

A total of 120 milk samples comprising thirty raw cow milk, thirty pasteurised cow milk, thirty raw goat milk and thirty pasteurized goat milk. All milk samples were collected from different collection points in Selangor area. This enables milk from different dairy chain being evaluated. The raw milk samples were collected from farms and milkman. The pasteurized milk samples were obtained from the marts and markets which includes night market, Ramadhan bazaar and agriculture fair. The pasteurisation was performed at $60^{\circ}$ $\mathrm{C}$ for 30 mins. Most of the samples were collected in the morning. Hence, all the milk samples able to be analysed once samples arrived at the lab on the same day.

Approximately $250-500 \mathrm{~mL}$ of the milk was aseptically collected and stored in clean bottles or plastic bag. During collection, milk samples were kept in the icebox to maintain chilled conditions and immediately sent to Food Safety and Quality Laboratory 2 in University Putra Malaysia for further analysis.

\subsection{Bacteriological analysis}

All the milk samples were analysed for the bacteriological quality as according to Fifteen schedule; Regulation 39 in Malaysia Food Act 1983 and Food Regulation 1985. The TPC, coliform count and E. coli count were carried out as described by Bacteriological Analysis Manual (BAM) USFDA (BAM, 2001).

For the TPC procedure, Plate Count Agar (PCA) (Sigma-Aldrich, USA) was used. The coliform count was determined using Violet Red Bile (VRB) agar (Sigma-Aldrich, USA). The E. coli count was determined using Eosin Methylene Blue (EMB) agar (Merck, Germany).

Initially, $10 \mathrm{~mL}$ of the milk sample was dispensed into a sterile stomacher bag containing $90 \mathrm{~mL}$ of sterile peptone water. The mixture was homogenised with stomacher for $60 \mathrm{~s}$. The subsequent dilution was prepared in peptone water up to $10^{-6}$. An amount of 100 $\mathrm{mL}$ of the milk mixture was incubated on the agar plates for $24 \mathrm{hrs}$ at $37^{\circ} \mathrm{C}$. The total bacterial count was calculated using colony counter (Galaxy 230).

\subsection{Statistical analysis}

The means of milk colony counts were analysed using one-way analysis of variance (ANOVA). Statistical significance difference between milk samples type of origin (cattle and goat) and type of milk (raw and pasteurised) were analysed. Minitab 17.0 statistical software (Minitab Inc. Pennsylvania, USA) was used to determine the difference in means of colony count. The data was analysed the data at $95 \%$ of confidence interval and $5 \%$ level of significance. All the plate counting assays were performed in triplicate of all types of milk samples. The colony counts were presented in $\log _{10}$ $\mathrm{CFU} / \mathrm{mL}$.

\section{Results}

\subsection{Milking practices}

All of the raw goat milk ( $\mathrm{n}=30)$ was collected using hand milking, while raw cow milk $(n=30)$ was collected using the line or portable milking. All farmers claimed that they cleaned the udder of the dairy animals prior to milking. 


\subsection{Total bacterial counts based on milk origins}

In this study, all types of milk were contaminated with bacteria and have exceeded the limit set by the Malaysia Food Act 1983 and Food Regulation 1985 (5 $\log _{10} \mathrm{CFU} / \mathrm{mL}$ ). Over $50 \%$ of the raw cow milk exceeded the standard, while pasteurised cow milk exceeded at $20 \%$. For raw goat milk, only $23 \%$ exceeded the standard and pasteurised goat milk at $47 \%$. From Table 1, the pasteurised goat milk account for the highest mean counts of TPC at $7.16 \log _{10} \mathrm{CFU} / \mathrm{mL}$. The lowest mean TPC was from pasteurised cow milk at $5.38 \log _{10} \mathrm{CFU} /$ $\mathrm{mL}$. The results showed that there are significant differences $(p<0.05)$ in the bacterial loads between different types of milk.

Table 1. Total plate count of bacteria based on milk origins

\begin{tabular}{ccc}
\hline Type & Origin & Total plate count $\left(\log _{10} \mathrm{CFU} / \mathrm{mL}\right)$ \\
\hline \multirow{2}{*}{ Raw } & Cow & $5.88 \pm 1.10^{\mathrm{ab}}$ \\
& Goat & $5.67 \pm 1.65^{\mathrm{ab}}$ \\
\hline \multirow{2}{*}{ Pasteurised } & Cow & $5.38 \pm 1.01^{\mathrm{b}}$ \\
& Goat & $7.16 \pm 1.75^{\mathrm{a}}$ \\
\hline
\end{tabular}

Values are mean \pm SD. Means with different alphabet superscript are significantly different at $p<0.05$.

Table 2 shows the mean counts for coliform and $E$. coli from local milk. Nearly $50 \%$ of all milk samples were contaminated with coliform. For coliform count, pasteurised goat milk recorded the highest mean counts of contamination at $6.54 \log _{10} \mathrm{CFU} / \mathrm{mL}$. For E. coli count, raw cow milk contaminated with $4.70 \log _{10} \mathrm{CFU} /$ $\mathrm{mL}$ while pasteurised goat milk was contaminated at the highest mean counts at $6.62 \log _{10} \mathrm{CFU} / \mathrm{mL}$. Pasteurised cow milk recorded the lowest mean count for both coliform and E. coli counts. The mean count for coliform and $E$. coli were significantly correlated at $\mathrm{r}=0.967$.

Table 2. Counts of coliform and E. coli in milk

\begin{tabular}{cccc}
\hline \multirow{2}{*}{ Type } & \multirow{2}{*}{ Origin } & \multicolumn{2}{c}{ Bacterial count $\left(\log _{10}\right.$ CFU $\left./ \mathrm{mL}\right)$} \\
\cline { 3 - 4 } & & Coliform & E. coli \\
\hline \multirow{2}{*}{ Raw } & Cow & $5.55 \pm 1.76^{\mathrm{a}}$ & $4.70 \pm 1.44^{\mathrm{a}}$ \\
& Goat & $4.59 \pm 1.13^{\mathrm{a}}$ & $3.92 \pm 0.91^{\mathrm{a}}$ \\
\hline \multirow{2}{*}{ Pasteurised } & Cow & $3.68 \pm 1.32^{\mathrm{a}}$ & $3.00 \pm 1.14^{\mathrm{a}}$ \\
& Goat & $6.54 \pm 1.83^{\mathrm{a}}$ & $6.62 \pm 1.97^{\mathrm{a}}$ \\
\hline
\end{tabular}

Values are mean \pm SD. Means with the same alphabet superscript are not significantly different at $p<0.05$.

\subsection{Total bacterial counts based on collection points}

Table 3. Total plate count of bacteria based on the collection points

\begin{tabular}{ccc}
\hline Type & Origin & Total plate count $\left(\log _{10} \mathrm{CFU} / \mathrm{mL}\right)$ \\
\hline \multirow{2}{*}{ Raw } & Farms & $4.62 \pm 1.20^{\mathrm{a}}$ \\
& Milkman & $6.17 \pm 1.31^{\mathrm{a}}$ \\
\hline \multirow{2}{*}{ Pasteurised } & Market & $7.11 \pm 1.77^{\mathrm{a}}$ \\
& Mart & $5.35 \pm 0.91^{\mathrm{a}}$ \\
\hline
\end{tabular}

Values are mean \pm SD. Means with the same alphabet superscript are not significantly different at $p<0.05$.
From Table 3, the TPC of milk from the delivery milkman, marts and markets have exceeded the limit set by the Malaysia Food Act 1983 and Food Regulation 1985. The milk from marts was at $5.35 \log _{10} \mathrm{CFU} / \mathrm{mL}$. The milk from markets was heavily contaminated with TPC at $7.11 \log _{10} \mathrm{CFU} / \mathrm{mL}$ while milk from delivery milkman recorded at $6.17 \log _{10} \mathrm{CFU} / \mathrm{mL}$. On the other hand, milk from farms recorded the lowest at $4.62 \log _{10}$ $\mathrm{CFU} / \mathrm{mL}$.

From statistical analysis, mean counts of raw milk from farms showed significant differences $(p<0.05)$ than raw milk from delivery milkman. However, there is no significant difference $(p>0.05)$ in the mean counts of raw milk with pasteurised milk.

\section{Discussion}

This study showed that all types of milk were heavily contaminated with bacteria. The TPC is an indicator for monitoring good sanitary practices during milk production, transportation and storage (Worku et al., 2012). In general, raw milk produced from healthy dairy animals under hygienic condition should not contain more than $10^{4}-10^{5} \mathrm{CFU} / \mathrm{mL}$ of bacteria (O' Connor, 1994). The high microbial load in milk might be linked to poor milking handling, poor animal health services and usage of contaminated water (Giacometti et al., 2012; Banik et al., 2014).

In this study, the TPC of raw cow milk was $5.88 \mathrm{log}$ $\log _{10} \mathrm{CFU} / \mathrm{mL}$. This was lower than the value reported by Chye et al. (2004) at $8.2 \log _{10} \mathrm{CFU} / \mathrm{mL}$ from local raw cow milk study. In contrast, for local raw goat milk, Suguna and research group reported that a slight lower TPC at $4.5 \log _{10} \mathrm{CFU} / \mathrm{mL}$ comparing to current study at $5.67 \log _{10} \mathrm{CFU} / \mathrm{mL}$ (Suguna et al., 2012).

Contamination can easily occur during the milking process. Insufficient udder cleaning may cause high bacterial contamination (Reta and Addis, 2015). A study in Ethiopia showed that $92 \%$ of the farmers have not washed the udder prior to milking and the mean TPC reached up to $1 \times 10^{12} \mathrm{CFU} / \mathrm{mL}$ (Abate et al., 2016). Besides, it is essential to dry the udder after washing as bacteria can grow in places with moist environment. In according to proper GMP, the correct way is to wash the udder with good quality of lukewarm water and unfragrance soap and this is yet to be implemented (Gemechu et al., 2014).

From observation, some dairy farms from this study were unable to practice good hygiene practices. The farmers did not clean the floor at milking area. This condition allows bacterial contamination from the milking area. Food Hygiene Regulations (2006) 
emphasise that milking area should be clean from any contamination sources like dust, flies, birds and other animals (Gemechu et al., 2014). One of the farms from this study allowed their dog to walk by the milking area and thus signify a point of concern. Additionally, farmed animals can be regarded as reservoirs of pathogens. This enables them to potentially transfer pathogens to milk which includes pathogenic E. coli, Staphylococcus aureus, Campylobacter spp., Salmonella spp. and Listeria monocytogenes (Farrokh et al., 2013).

Temperature has influences high bacterial counts. Milk samples from the market were exposed to a higher temperature in comparing with milk sample from mart as there is no proper refrigerator while selling the milk at the market. Furthermore, Malaysia weather is characterised as warm temperatures (mean $>17^{\circ} \mathrm{C}$ ) and abundant rainfall $(250-2000 \mathrm{~mm})$. The temperature fluctuates between $23-34^{\circ} \mathrm{C}$ and relative humidity between 60-95\% (Sithambaram and Nizam, 2013). Without right cold chain from farm to processing plant and finally retail points, the bacterial counts can significantly increase together with the warm Malaysia weather.

The pasteurised goat milk in this study was heavily contaminated. Due to heat treatment, this is not expected in pasteurised milk. This can be influenced by poor initial milk quality, defective in pasteurisation machinery, possible post pasteurisation contamination. Post contamination can arise from poor milk processing, unhygienic handling conditions and temperature abuse during storage (Omore et al., 2005; Banik et al., 2014; Piotrowska et al., 2015). Finally, all these factors can contribute to high total bacterial counts.

Some of the pasteurised goat milk was purchased from market. When the mean counts of TPC were analysed based on collection points, it was clear that milk from delivery milkman and market recorded the highest contamination of bacteria. The night market seller from this study used ice to maintain the temperature, which as time passes the ice melted. Besides, milkman delivery from this study selling the milk without putting the milk in the ice container. This highlighted the importance of cold chain at milk sale points.

The pasteurised cow milk, however, showed contamination at only $20 \%$ of the milk samples exceed the standard limit. This proves that the pasteurisation is a necessary step and the milk samples lack secondary contamination. This can also be attributed from the use of chilling facilities as some of the pasteurised cow milk was bought from the mart.
According to the Malaysia Food Act 1983 and Food Regulation 1985, the coliform should be less than 50 $\mathrm{CFU} / \mathrm{mL}$ in raw milk. However, this study showed present of coliform bacteria found in both raw and pasteurised milk. Coliform bacteria is the indicator for faecal contamination in milk. It may also indicate usage of contaminated water, unsanitary milking practices, not maintaining milking equipment and not washed them properly (Banik et al., 2014). It is suspected that high coliform count may arise from unsanitary practices during and after milking, rather than faecal contamination. From observation, the dairy goats in this study were reared on raised slatted floored housing system hence can be easily cleaned. The goat dungs can easily fall down through the floor. Additionally, goat's faeces are in pelleted form and easily dried. Therefore, direct faecal contamination is reduced compared to what would occur in cow milk.

Besides that, locally produced - raw cow and goat milk were packed in the plastic container (usually in 250 $\mathrm{mL}$ for goat milk and $500 \mathrm{~mL}$ for cow milk) from different farms and are available for sale to consumers at small shops or night market (Noted that, after December 2016, no raw milk is legally sold in Malaysia). The usage of plastic container has been associated with high coliform counts in raw milk as plastic is difficult to be cleaned and sterile (Omore et al., 2005). Unlike the established dairy companies, they use milk cartoon that suitable are for dairy product packaging. This is yet to be reinforced to the smallholder dairy industries in Malaysia.

In general, the bacterial counts increased as the milk reached the last selling point, market. They sell at high bacterial counts compared to milk from the farm (initial places) and mart (good cold chain system). This reflected from prolonged storage at high temperature. Additionally, Worku and team (2012) agreed that the selling of milk through milkman delivery was commonly practiced with no quality control like no registration system and no communication between authorities and farmers. Hence, the quality of the milk is always subjected to deterioration and imposed a high risk to the consumers.

\section{Conclusion}

In this study, the finding show bacteriological quality of raw and pasteurised milk of cow and goat milk were not at a satisfactory level. This can be indicated by high bacterial counts from TPC as well as coliform and E. coli counts. Pasteurised milk should have lower bacterial counts, but not in this study. Proper refrigeration temperature during transportation, storage 
as well as in farms should be maintained to ensure that milk is at good quality. Among the factors that contribute to low milk, quality are unhygienic handling during milk processing and the absence of cold chains. Training in milk hygiene and quality testing as well as maintaining correct chilling system will be able to improve the quality of milk.

\section{Acknowledgement}

This research was financially supported by Research University Grant Scheme Initiative Six (RUGS 6) of Universiti Putra Malaysia (GP-IPS 9438703 and GP-IPS 9466100) and Fundamental Research Grant Scheme (FRGS) of Ministry of Higher Education (MOHE), Malaysia (02-01-14-1475FR).

\section{References}

Abate, M., Wolde, T. and Niguse, A. (2016). Bacteriological quality and safety of raw cow 's milk in and around Jigjiga City of Somali Region, Eastern Ethiopia. International Journal of Research Studies in Biosciences (IJRSB), 3(5), 48-55.

Angelidis, A.S., Tsiota, S., Pexara, A. and Govaris, A. (2016). The microbiological quality of pasteurized milk sold by automatic vending machines. Letters in Applied Microbiology, 62(6), 472-479. https:// doi.org/10.1111/lam.12572

Banik, S.K., Das, K.K. and Uddin, M.A. (2014). Microbiological quality analysis of raw, pasteurized, UHT milk samples collected from different locations in Bangladesh assay. Stamford Journal of Microbiology, 4(1), 5-8.

Chatterjee, S.N., Bhattacharjee, I., Chatterjee, S.K. and Chandra, G. (2006). Microbiological examination of milk in Tarakeswar, India with special reference to coliforms. Journal of Biotechnology, 5, 1383-1385.

Chye, F.Y., Abdullah, A. and Ayob, M.K. (2004). Bacteriological quality and safety of raw milk in Malaysia. Food Microbiology, 21(5), 535-541. https://doi.org/10.1016/j.fm.2003.11.007

Farrokh, C., Jordan, K., Auvray, F., Glass, K., Oppegaard, H., Raynaud, S., Thevenot, D., Condron, R., Reu, K.D., Govaris, A., Heggum, K., Heyndrickx, M., Hummerjohann, J., Lindsay, D., Miszczycha, S., Moussiegt, S., Verstraete, K. and Cerf, O. (2013). Review of Shiga-toxin-producing Escherichia coli (STEC) and their significance in dairy production. International Journal of Food Microbiology, 162(2), 190-212. https:// doi.org/10.1016/j.ijfoodmicro.2012.08.008

Gemechu, T., Beyene, F. and Eshetu, M. (2014). Handling practices and microbial quality of raw cow 's milk produced and marketed in Shashemene Town. International Invention Journal of Agricultural and Soil Science, 2(9), 153-162. https:// doi.org/10.5897/ISABB-JFAS2014.0017

Muehlhoff, E., Bennett, A. and McMahon, D. (2013). Milk and dairy products in human nutrition, p. 1344. Rome: Food and Agriculture Organization of the United Nations.

Omore, A., Lore, T., Staal, S., Kutwa, J., Ouma, R., Arimi, S. and Kang'ethe, E. (2005). Addressing the public health and quality concerns towards marketed milk in Kenya, p. 1-14. SDP Research and Development Report No. 3 Kenya: Smallholder Dairy (R\&D) Project

Petrus, R.R., Loiola, C.G. and Oliveira, C.A.F. (2010). Microbiological shelf life of pasteurized milk in bottle and pouch. Journal of Food Science, 75(1), 36 $-40 . \quad$ https://doi.org/10.1111/j.17503841.2009.01443.x

Piotrowska, A., Świderski, F., Kostyra, E., ŻebrowskaKrasuska, M. and Sadowska, A. (2015). Microbiological and sensory quality of milk on the domestic market. Polish Journal of Food and Nutrition Sciences, 65(4), 261-267. https:// doi.org/10.1515/pjfns-2015-0008

Reta, M.A. and Addis, A.H. (2015). Microbiological quality assessment of raw and pasteurized milk. International Journal of Food Science and Microbiology, 2(6), 87-91.

Sithambaram, S. and Nizam, Q.N.H. (2013). Country Reports 2013/14 of the Asian Australasian Dairy Goat Network, p. 57-65. Malaysia: Institute of Tropical Agriculture Universiti Putra Malaysia.

Suguna, M., Rajeev, B. and Wan Nadiah, W.A. (2012). Microbiological quality evaluation of goat milk collected from small-scale dairy farm in Penang Island, Malaysia. International Food Research Journal, 19(3), 1241-1245.

Worku, T., Negera, E., Nurfeta, A. and Welearegay, H. (2012). Microbiological quality and safety of raw milk collected from Borana pastoral community, Oromia Regional State. African Journal of Food Science and Technology, 3(9), 213-222.

Yuen, S.K., Yee, C.F. and Yin, F.H. (2012). Microbiological quality and the impact of hygienic practices on the raw milk obtained from the smallscale dairy farmers in Sabah, Malaysia. International Journal of Agricultural and Food Science, 2(2), 5559. 